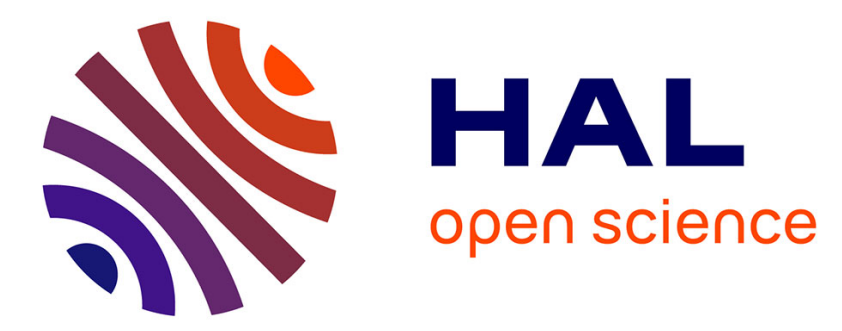

\title{
Irrigation, soil organic carbon and N2O emissions. A review
}

\author{
Benjamin Trost, Annette Prochnow, Katrin Drastig, Andreas Meyer-Aurich, \\ Frank Ellmer, Michael Baumecker
}

\section{- To cite this version:}

Benjamin Trost, Annette Prochnow, Katrin Drastig, Andreas Meyer-Aurich, Frank Ellmer, et al.. Irrigation, soil organic carbon and $\mathrm{N} 2 \mathrm{O}$ emissions. A review. Agronomy for Sustainable Development, 2013, 33 (4), pp.733-749. 10.1007/s13593-013-0134-0 . hal-01201385

\section{HAL Id: hal-01201385 \\ https://hal.science/hal-01201385}

Submitted on 17 Sep 2015

HAL is a multi-disciplinary open access archive for the deposit and dissemination of scientific research documents, whether they are published or not. The documents may come from teaching and research institutions in France or abroad, or from public or private research centers.
L'archive ouverte pluridisciplinaire HAL, est destinée au dépôt et à la diffusion de documents scientifiques de niveau recherche, publiés ou non, émanant des établissements d'enseignement et de recherche français ou étrangers, des laboratoires publics ou privés. 


\title{
Irrigation, soil organic carbon and $\mathrm{N}_{2} \mathrm{O}$ emissions. A review
}

\author{
Benjamin Trost • Annette Prochnow • Katrin Drastig • \\ Andreas Meyer-Aurich • Frank Ellmer • \\ Michael Baumecker
}

Accepted: 18 January 2013 / Published online: 20 February 2013

(C) INRA and Springer-Verlag France 2013

\begin{abstract}
Irrigation has a critical role for crop production worldwide. In particular, irrigation is a major issue due to the growing food demand and climate change. Irrigation affects yields and the emission of greenhouse gases such as $\mathrm{CO}_{2}$ and $\mathrm{N}_{2} \mathrm{O}$ by soils. Here, we review the effect of irrigation on soil organic carbon and $\mathrm{N}_{2} \mathrm{O}$ emissions. We
\end{abstract}

B. Trost $(\bowtie) \cdot$ A. Prochnow $\cdot$ K. Drastig $\cdot$ A. Meyer-Aurich Leibniz-Institute for Agricultural Engineering Potsdam-Bornim, Max-Eyth-Allee 100,

14469 Potsdam, Germany

e-mail: btrost@atb-potsdam.de

\section{A. Prochnow}

e-mail: aprochnow@atb-potsdam.de

A. Prochnow

e-mail: annette.prochnow@agrar.hu-berlin.de

K. Drastig

e-mail: kdrastig@atb-potsdam.de

A. Meyer-Aurich

e-mail: ameyer@atb-potsdam.de

\section{A. Prochnow}

Chair Utilization Strategies for Bioresources, Faculty of Agriculture and Horticulture, Humboldt-University of Berlin, Hinter der Reinhardtstr. 8-18,

10115 Berlin, Germany

\section{F. Ellmer}

Division of Agronomy and Crop Science, Faculty of Agriculture and Horticulture, Humboldt-University of Berlin, Albrecht-Thaer-

Weg 5,

14195 Berlin, Germany

e-mail: frank.ellmer@agrar.hu-berlin.de

\section{Baumecker}

Field Study and Research Station, Faculty of Agriculture and Horticulture, Humboldt-University of Berlin, Dorfstraße 9, 14974 Thyrow, Germany

e-mail: michael.baumecker@agrar.hu-berlin.de analysed 22 investigations in various regions of the world. Interactions between irrigation, soil and management factors are described. The main points are: (1) The influence of irrigation is strongly dependent on climate and initial soil organic carbon content. For instance, irrigation of cultivated desert soils led to an average increase of $90 \%$ to over $500 \%$ of soil organic carbon. (2) Irrigation of semiarid regions increases soil organic carbon by $11 \%$ to $35 \%$. (3) No consistent effects of irrigation were observed in humid regions. In many cases, $\mathrm{N}_{2} \mathrm{O}$ emissions increase after precipitation or irrigation. (4) Comparison of $\mathrm{N}_{2} \mathrm{O}$ emissions from irrigated and non-irrigated fields shows that availability of reactive nitrogen compounds controls increased $\mathrm{N}_{2} \mathrm{O}$ emissions under irrigation, in most cases. Here, increases of about $50 \%$ to $140 \%$ in $\mathrm{N}_{2} \mathrm{O}$ emissions were reported.

Keywords Irrigation $\cdot$ Soil organic carbon $\cdot$ Nitrous oxide emissions

\section{Introduction}

Agriculture today is facing unprecedented challenges. The world population will grow from 6.9 billion people in 2010 to an estimated 9.15 billion people in 2050 (Alexandratos and Bruinsma 2012). At the same time, the individual food energy intake will increase from 2,850 to $3,130 \mathrm{kcal}$ per capita and day (Bruinsma 2009). These trends will apply pressure on resources needed for agricultural production such as land, water and energy, and increase greenhouse gas emissions from agriculture. The situation is expected to be aggravated further by climate change (Alexandratos and Bruinsma 2012). Irrigation is an important means to ensure water supply for crop production and to adapt agriculture to increasing water scarcity due to climate change. On the other hand, irrigation itself might affect climate by altering 
the capacity of soils to act as sinks or sources of greenhouse gases, in particular, $\mathrm{CO}_{2}$ and $\mathrm{N}_{2} \mathrm{O}$ (Lal 2004). Hence, it is desirable to understand the interactions between climate and irrigation. Water availability is an important factor for crop production (Fig. 1) and also for the amount of organic residues in soils. In many regions of the world, water deficiency is one of the most yield-restricting factors. Due to drought and water deficiency, only $30 \%$ of worldwide maximum attainable yields are approached (Deng et al. 2005). The use of irrigation to overcome the lack of reliable rainfall is growing worldwide. Around the world 306,247,000 ha of agricultural land are irrigated. That is $22.1 \%$ of the arable land and $6.2 \%$ of the worldwide agricultural area (FAO Statistical Yearbook 2010). The importance of irrigation is expected to grow further to meet the rising global demand for agricultural products and to adapt to increasing water scarcity due to climate change. Table 1 shows the current distribution of area equipped for irrigation for different continents and selected countries. Despite the huge relevance for worldwide agricultural production, the potential contribution of irrigation to net greenhouse gas emissions is little investigated compared with other agronomic activities (King et al. 2009).

The objective of this review is to compile results from 22 investigations about the impact of irrigation on soil organic carbon contents and $\mathrm{N}_{2} \mathrm{O}$ emissions. Furthermore, the underlying processes and interactions of irrigation with other management factors such as tillage and fertilisation are discussed. Conclusions on potential effects of irrigation on net greenhouse gas emissions and necessary further research are drawn.

\section{Basic effects of irrigation on $\mathrm{CO}_{2}$ and $\mathrm{N}_{2} \mathrm{O}$ emission processes}

Irrigation may influence the $\mathrm{CO}_{2}$ and $\mathrm{N}_{2} \mathrm{O}$ emissions of arable land via several processes. Some processes make soil a sink for $\mathrm{CO}_{2}$ while others may promote a release (Fig. 2).

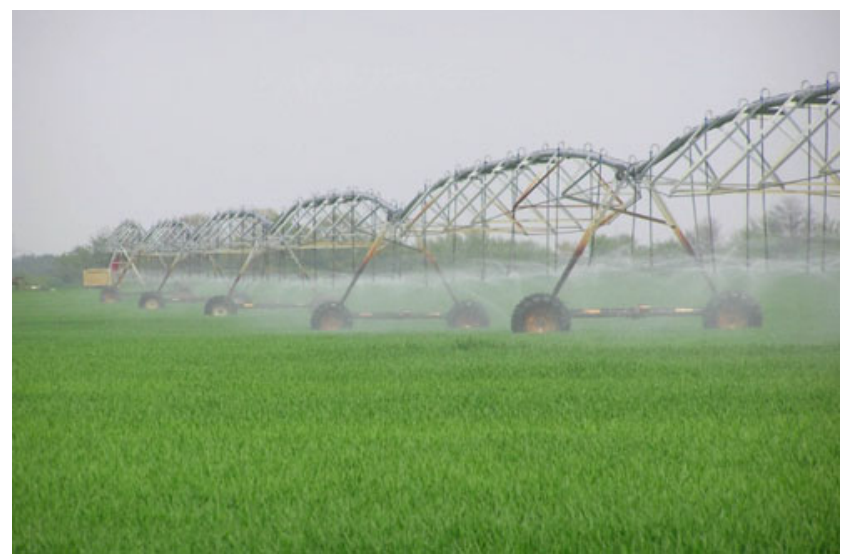

Fig. 1 Irrigation, an essential factor in crop production
Table 1 Irrigated area (data from FAO Statistical yearbook 2010)

\begin{tabular}{|c|c|}
\hline Region & $\begin{array}{l}\text { Irrigated area, ha } \\
(2008)\end{array}$ \\
\hline World & $306,247,000$ \\
\hline Asia & $195,461,000$ \\
\hline India & $62,286,000$ \\
\hline China & $64,141,000$ \\
\hline Pakistan & $19,870,000$ \\
\hline Afghanistan & $3,199,000$ \\
\hline Europe & $29,564,000$ \\
\hline Russia & $4,346,000$ \\
\hline Italy & $3,950,000$ \\
\hline Spain & $3,800,000$ \\
\hline Romania & $3,157,000$ \\
\hline North and Central America & $31,968,000$ \\
\hline USA & $23,000,000$ \\
\hline Mexico & $6,300,000$ \\
\hline Cuba & 870,000 \\
\hline Canada & 855,000 \\
\hline South America & $12,082,000$ \\
\hline Brazil & $4,500,000$ \\
\hline Argentinia & $1,550,000$ \\
\hline Peru & $1,195,000$ \\
\hline Colombia & 900,000 \\
\hline Africa & $13,576,000$ \\
\hline Egypt & $3,530,000$ \\
\hline Sudan & $1,863,000$ \\
\hline South Africa & $1,498,000$ \\
\hline Morocco & $1,457,000$ \\
\hline Middle East & $22,277,000$ \\
\hline Iran & $8,993,000$ \\
\hline Turkey & $5,215,000$ \\
\hline Iraq & $3,525,000$ \\
\hline Saudi Arabia & $1,731,000$ \\
\hline Australia & $2,550,000$ \\
\hline
\end{tabular}

An improved water supply leads, on the one hand, to an increased biomass generation and therefore to a higher input of carbon into the soil in the form of roots and dead plant material (Entry et al. 2008; Kochsiek et al. 2009; Roldan et al. 2005). On the other hand, the application of water and consequently higher soil moisture enhances soil microbial activity. This may result in an increased decomposition of soil organic matter and therefore in rising $\mathrm{CO}_{2}$ emissions (Jabro et al. 2008; Kochsiek et al. 2009; Liu et al. 2008). The increased microbial decomposition of soil organic matter may lead to lower soil organic carbon contents (Dersch and Bohm 2001; Getaneh et al. 2007).

The effects of irrigation on soil organic carbon content not only depend on the decrease or increase in soil moisture. 
Fig. 2 Basic effects of irrigation on soil organic carbon content and nitrous oxide $\left(\mathrm{N}_{2} \mathrm{O}\right)$ emissions (increase, decrease)

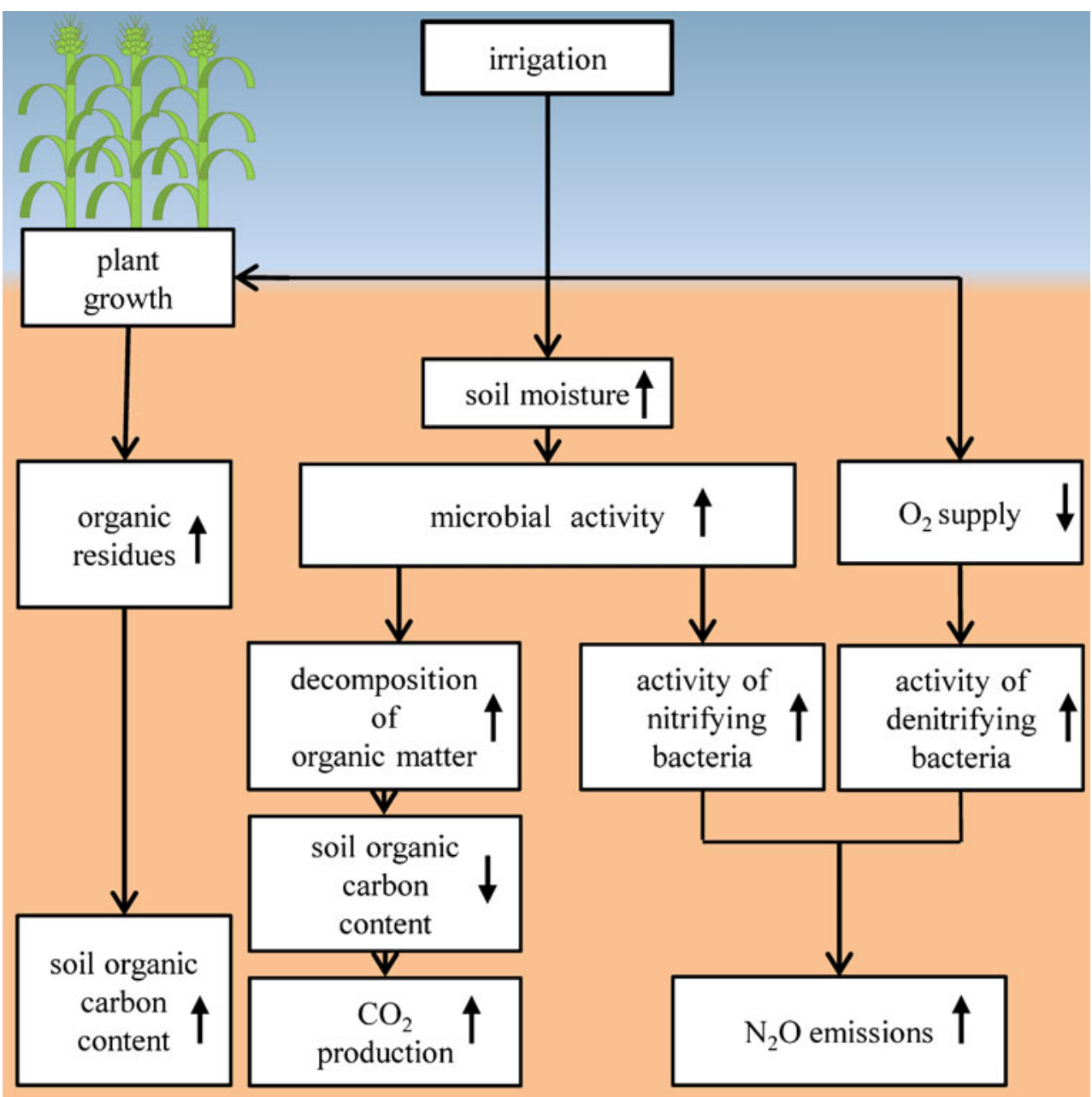

The interaction with other factors like fertilisation, tillage or the activity of soil organisms may also influence the development of soil organic carbon.

Another important greenhouse gas emitted from arable land and influenced by irrigation is $\mathrm{N}_{2} \mathrm{O}$. Nitrification and denitrification are the main processes for $\mathrm{N}_{2} \mathrm{O}$ formation (Bremner 1997; Phillips 2008), and both irrigation and precipitation can influence these microbial processes. Improved living conditions for microorganisms by increased soil moisture may cause enhanced activity of nitrifying bacteria (Jha et al. 1996). An increase in water-filled pore volume over $70 \%$ may lead to reduced soil aeration resulting in low oxygen concentrations to anaerobic conditions which support denitrification (Amha and Bohne 2011; Ruser et al. 2006; Scheer et al. 2008). An increased soil microbial activity may lead to a decrease in the soil oxygen concentration as well (Loecke and Robertson 2009; Potthoff et al. 2005). Thus, irrigation may contribute to $\mathrm{CO}_{2}$ mitigation and simultaneously enhance $\mathrm{N}_{2} \mathrm{O}$ emissions. Increased $\mathrm{N}_{2} \mathrm{O}$ emissions might reduce or offset a potential positive effect of enhanced carbon sequestration (Ball et al. 2008; Chatskikh and Olesen 2007; Li et al. 2005; Smith et al. 2000).

\section{Soil carbon contents under irrigation}

\subsection{Overview of long-term field experiments}

An overview of 14 long-term field experiments created to observe the soil carbon content under irrigation compared with non-irrigation is given in Table 2. In some cases, soil organic carbon contents were significantly higher under irrigation, while other results do not show significant differences between the treatments.

Several experiments on the development of soil organic carbon contents on irrigated and non-irrigated plots were conducted in arid or semiarid regions where irrigation is essential for crop production. Denef et al. (2008) conducted investigations in an arid region of the USA. The improved water availability under irrigation led to an increase in biomass production and thus, to an accumulation of organic matter in the soil. As a consequence, the contents of soil organic carbon were significantly higher than in the nonirrigated cultivated plots. However, on the experimental site with the higher precipitation, the highest soil organic carbon contents were found on plots with natural vegetation. 


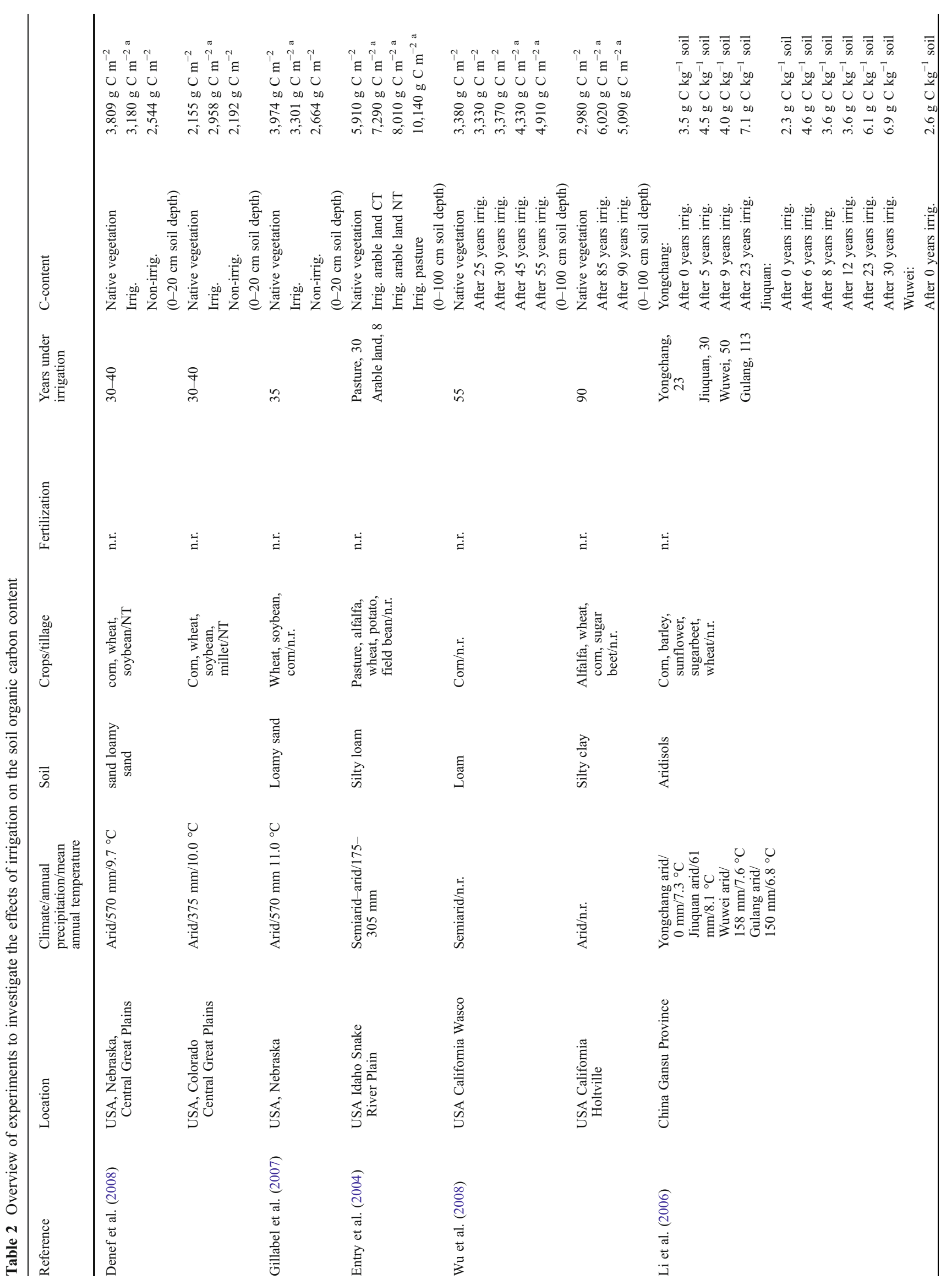




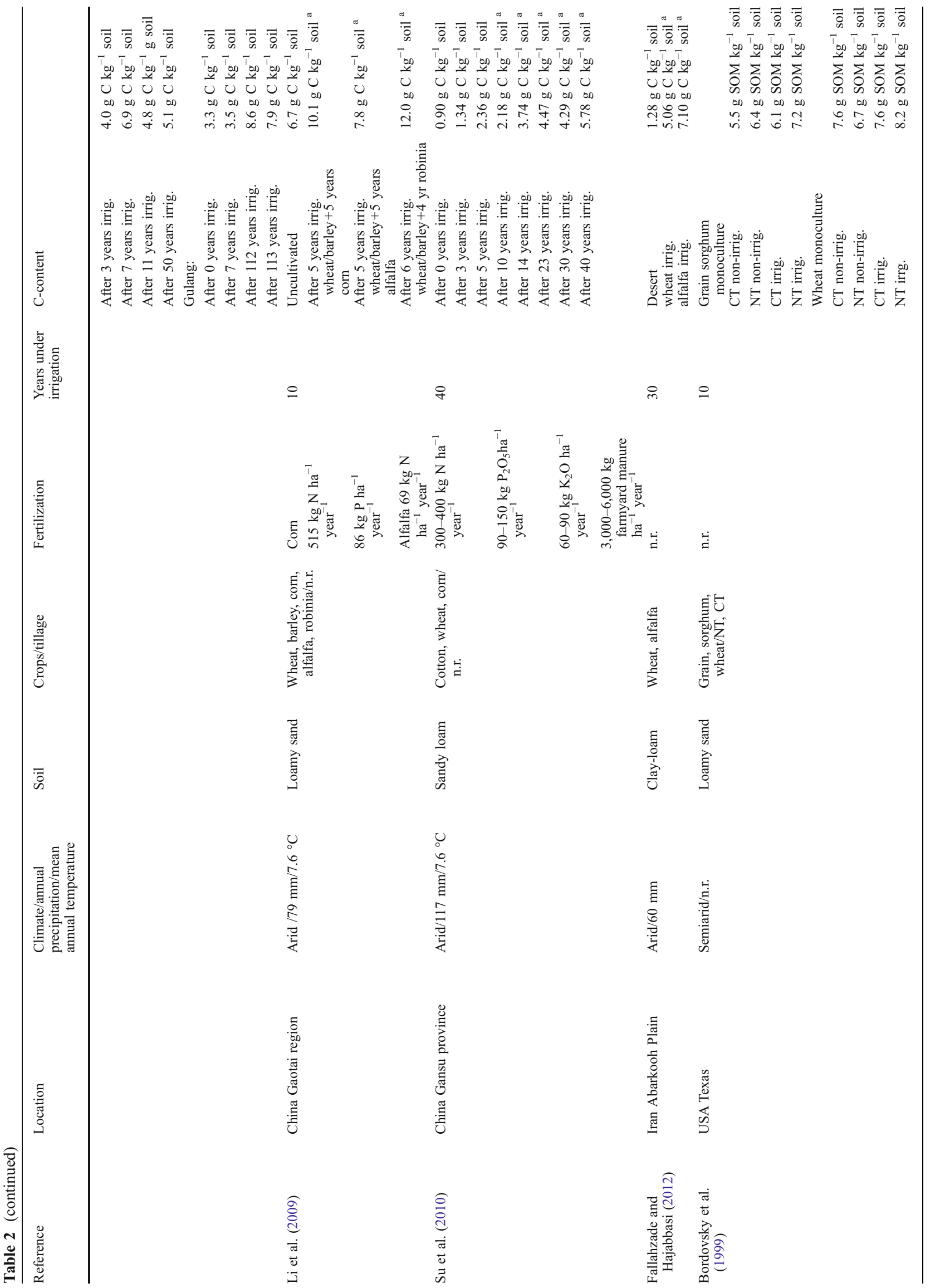




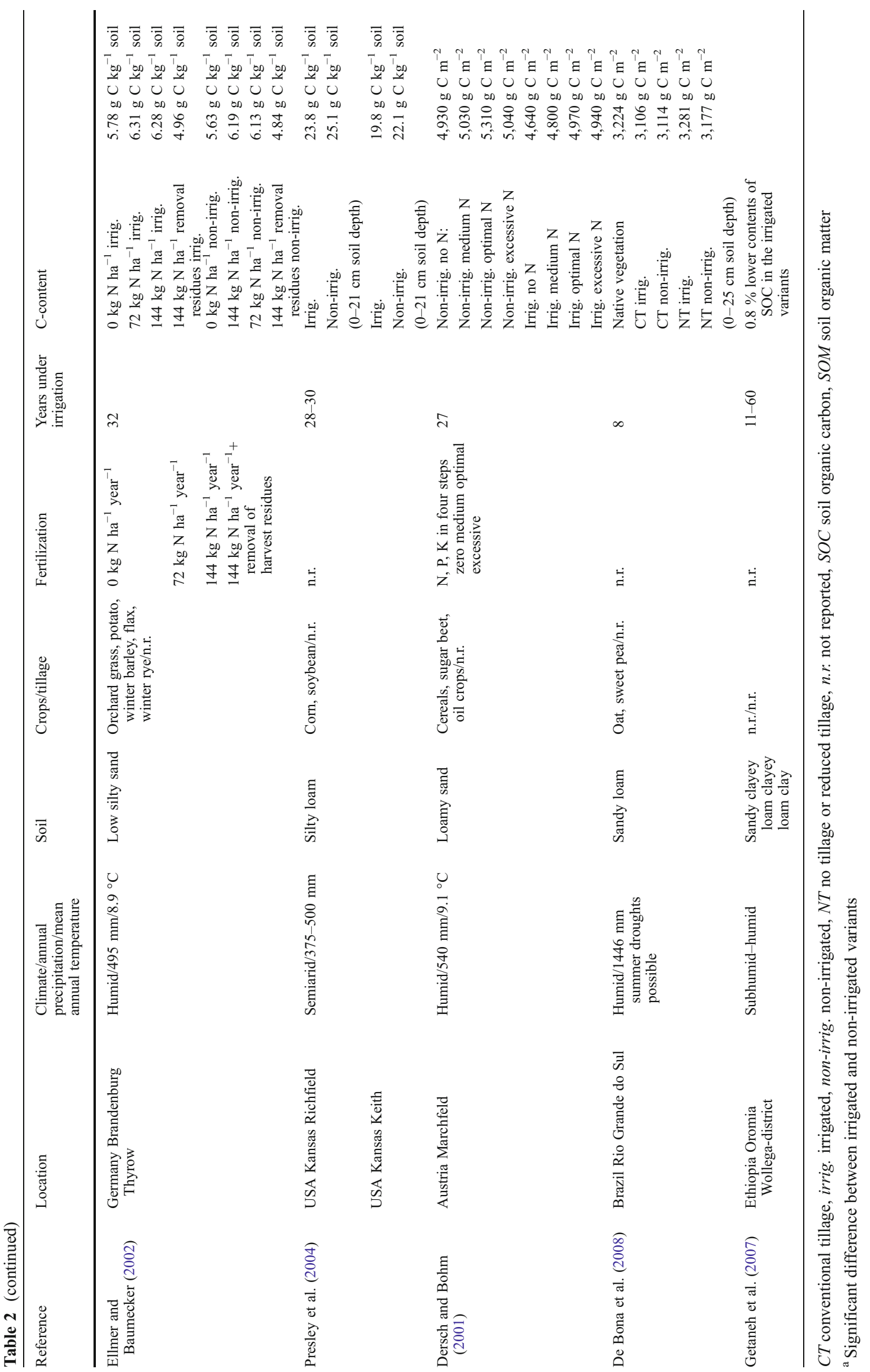


Gillabel et al. (2007) also observed higher soil carbon contents in an arid region in fields irrigated for 30 years in the USA. Irrigation led to a better plant growth and thus to a high input of organic carbon by harvest residues. Also, in this case, the highest soil organic carbon contents were obtained in the plots under natural vegetation. After 30 years of investigations, Entry et al. (2004) found higher soil carbon contents in irrigated arable land compared with non-irrigated plots and natural steppe vegetation in a semiarid to arid region in the USA. Here, the soil organic carbon contents on plots with natural vegetation were lower than on plots under cultivation.

Similar effects were detected by $\mathrm{Wu}$ et al. (2008) who analyzed data from 50 to 90 years of experiments in the USA comparing irrigated arable land with native vegetation in an arid and semiarid climate. They found that the carbon content was significantly higher in the irrigated arable land after 30 years. Li et al. (2006) investigated changes in soil carbon content in an arid region of China after converting desert to irrigated arable land. Some years after conversion, the soil carbon contents in all crop rotations studied were higher than under desert vegetation. The large difference in biomass production between desert and irrigated arable land was reported to be probably the main reason for the fast increase in soil organic carbon. Similar results were found by $\mathrm{Li}$ et al. (2009) and $\mathrm{Su}$ et al. (2010). A significant difference in soil organic carbon content was observed 10 years after the change from uncultivated dry land to irrigated and fertilised cropland. Irrigation and fertilisation led to a strong increase in plant growth and, thus, to a higher input of organic matter into the soil. Similar results were reported by Fallahzade and Hajabbasi (2012) whose investigations were conducted in Iran to analyse the effects of converting desert to irrigated cropland. In contrast, Bordovsky et al. (1999) found only slightly higher contents of soil organic matter 10 years after implementation of irrigation in a semiarid region in the USA.

The situation is different if precipitation is higher or soils have higher initial soil organic carbon content. In Germany (humid climate) (Fig. 3), Ellmer and Baumecker (2002) found slightly but not significantly higher soil organic carbon contents after 32 years of irrigation (Table 2). Presley et al. (2004) reported that no differences in the soil organic carbon content were observed on soils with higher initial contents after 28 to 30 years of irrigation on plots in a semiarid region the USA. After 27 years of field trials in Austria (humid climate), Dersch and Bohm (2001) did not find significant differences in the soil organic carbon content between irrigated and non-irrigated plots. The authors assume increased mineralisation under irrigation to be the reason. Mineralisation decreased during dry periods in the non-irrigated plots while it was not reduced under irrigation. The same effect seems to predominate in the investigations

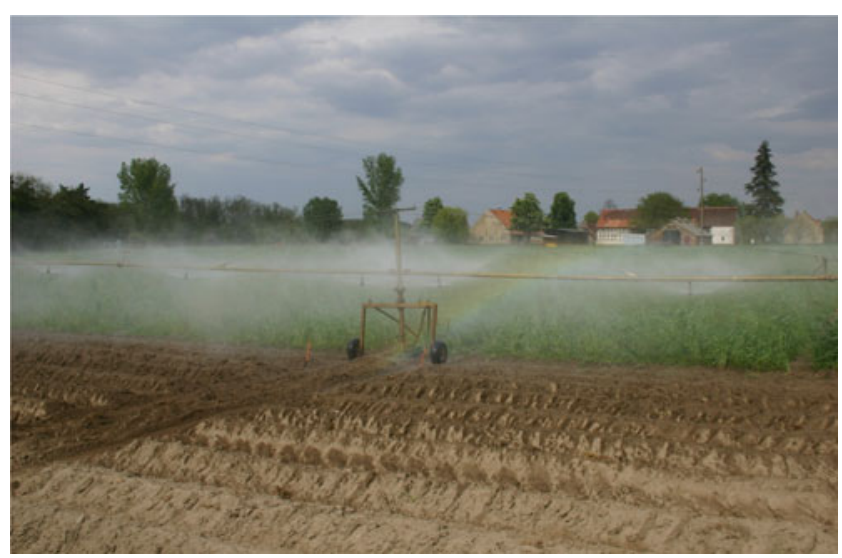

Fig. 3 Long-term irrigation field trial in Germany

of De Bona et al. (2008). They also found no significant differences in soil organic carbon contents between irrigated and non-irrigated plots after 10 years of investigation in Brazil.

Getaneh et al. (2007) report a slight and not significant decrease in soil organic carbon from plots in a subhumid to humid region of Ethiopia. In this experiment, over 11 to 60 years, the high cultivation intensity and the complete removal of harvest residues are crucial. The increased soil moisture under irrigation enhanced microbial activity, and the input of organic matter was too low to compensate the increased decomposition.

In summary, among the 14 long-term field experiments shown in Table 2, there were eight cases where significantly higher soil organic carbon contents under irrigation were obtained. All of these investigations were carried out on arid or desert sites. Especially on desert or arid sites with low precipitation, scanty natural vegetation and low initial soil organic carbon contents irrigation led to increases in soil organic carbon. In semiarid and arid regions with a better natural plant growth and higher precipitation, soil organic carbon contents of irrigated and non-irrigated arable land were generally lower than those of sites with natural vegetation. However, among the plots used as arable land, irrigation led to higher soil organic carbon contents compared with non-irrigation.

No significant differences between irrigated and nonirrigated plots or slight decreases in soil organic carbon contents were found in six cases. These investigations were conducted in wetter regions like Germany, Austria and Brazil and on arable soils with higher initial soil organic carbon content. The potential for decomposition of soil organic carbon is higher in these regions. Ogle et al. (2005) investigated the loss of soil organic matter after change from natural vegetation to arable land in different climates. The largest difference was found in the humid tropics. The differences between soil organic matter contents under natural vegetation and arable land decrease with 
increased aridity and decreased mean annual temperature. The analysis of the 14 long-term investigations has shown a similar result. Figure 4 shows a summary of all 14 investigations, ordered by climate and land use. The largest changes were found on irrigated desert soil with an average increase in soil organic carbon of $242.6 \%$. In contrast, the average increase in regions with higher precipitation was smaller, about 17 to $25 \%$ in arid or semiarid climates. In some cases, soil organic carbon even decreased. In humid climates, irrigation showed a minimal effect. The mean increase in all investigations of this climate was about 2.0. Also, the duration of experiments plays an important role in investigations on the development of soil organic carbon contents. In order to study significant changes in soil organic carbon, long-term experiments are necessary ( $\mathrm{Li}$ et al. 1997). Results will be more meaningful with an increasing duration of investigations on equal terms.

In the reviewed investigations, further management factors like tillage and fertilisation were also varied. Hence, the observed effects on soil organic carbon content might be the consequence of interaction of irrigation and other management factors. These factors are discussed below.

\subsection{Interaction of irrigation and $\mathrm{N}$ fertilisation}

When considering the effects of irrigation, possible interactions with other agrotechnical activities have to be regarded. One of such activity is $\mathrm{N}$ fertilisation.

Many investigations show that $\mathrm{N}$ fertilisation leads to higher biomass generation and to an increase in root and harvest residues. Thus, $\mathrm{N}$ fertilisation may contribute to increase the soil organic carbon content in arable land (Liu and Greaver 2009; Schlesinger 2000). On the other hand, N fertilisation may lead to a decrease in the soil carbon/nitrogen ratio and hence to a higher decomposability of soil organic matter (Li et al. 2009).

Field experiments that allow for observing the interaction between irrigation and $\mathrm{N}$ fertilisation are rare. Among the investigations listed in Table 2, only Ellmer and Baumecker (2002) and Dersch and Bohm (2001) include varying N fertilisation rates on irrigated and non-irrigated plots. Both report that plots with $\mathrm{N}$ fertilisation have higher soil organic carbon contents than plots without $\mathrm{N}$ fertilisation at the same intensity of irrigation. As previously mentioned, they did not observe additional increases in soil organic carbon contents by irrigation.

change in soil organic carbon content (\%)

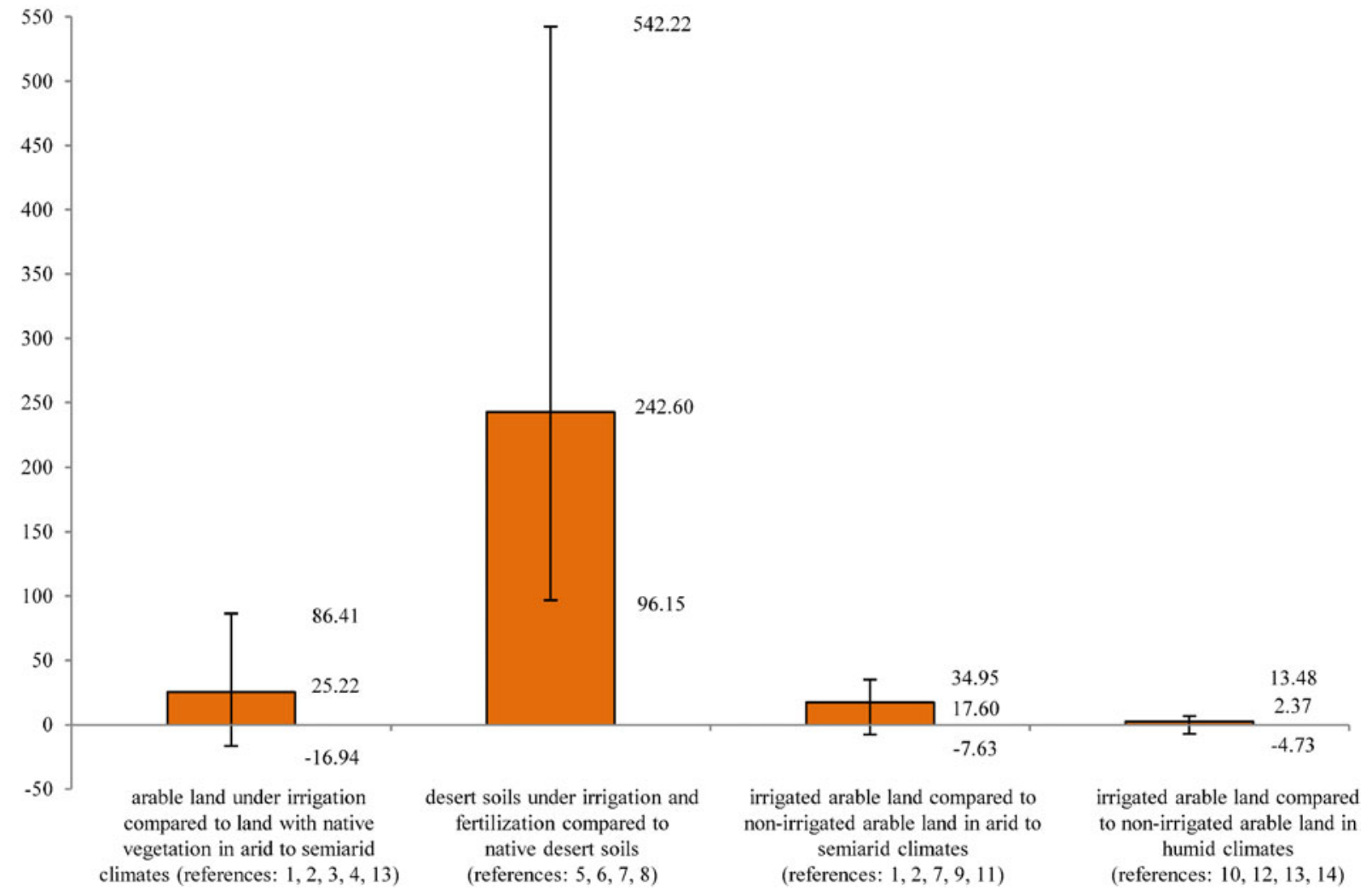

Fig. 4 Changes (mean, minimum maximum) in soil organic carbon content under irrigation compared with non-irrigated conditions and native vegetation in different climes, based on 14 long-term investigations (references: $1=$ Denef et al. (2008); $2=$ Gillabel et al. (2007); $3=$ Entry et al. (2004); $4=\mathrm{Wu}$ et al. (2008); $5=\mathrm{Li}$ et al. (2006); $6=\mathrm{Li}$ et al.
(2009); $7=\mathrm{Su}$ et al. (2010); $8=$ Fallahzade and Hajabbasi (2012); $9=$ Bordovsky et al. (1999); 10=Ellmer and Baumecker (2002); $11=$ Presley et al. (2004); 12=Dersch and Böhm (2001); 13=De Bona et al. (2008); 14=Getaneh et al. (2007)) 


\subsection{Interaction of irrigation and tillage}

The intensity of tillage may affect the soil organic carbon content remarkably due to its effects on soil physical and biological conditions. Bulk density, pore volume and, thus, aeration and water infiltration are strongly influenced (Amézketa 1999; Šimon et al. 2009; Stubbs et al. 2004). With regard to the combined impact of tillage and irrigation, two effects are relevant. One is the independent effect of tillage intensity on soil organic carbon. The second effect results from the influence of tillage intensity on water productivity.

Conservation tillage is well-known to be humuspreserving and leads to soil organic matter accumulation as a rule (Rusu et al. 2008). While conventional tillage causes a strong disaggregation and aeration of soil, thus supporting the decomposition of organic matter by increased oxygen availability, the impact on soil structure is strongly reduced under conservational tillage and especially under no-till. Harvest residues are shallowly incorporated into the soil or remain on the soil surface. The increasing amount of organic matter protects the soil against wind and water erosion and stimulates the edaphon (Šimon et al. 2009; Stubbs et al. 2004).

Reduced or no-tillage contribute as well to increasing water productivity, i.e., the amount of crop output generated per unit water input. Both reduced and no tillage increases the soil's water storage capacity due to humus preservation and decreased evaporation from soil. In the case of no-till, additional air moisture can be absorbed into the mulch cover. Altogether, reduced tillage and no-till may increase biomass generation per unit of water input via precipitation and irrigation and, thus, enlarge the potential positive effect of irrigation on soil carbon sequestration (Drastig et al. 2011; Rusu et al. 2008).

Consequently, the combination of irrigation and reduced tillage is assumed to have a larger potential to increase soil organic carbon contents than irrigation in combination with conventional tillage (Martens et al. 2005). This is confirmed by the results of Entry et al. (2004) and Bordovsky et al. (1999) (Table 2). Significantly higher soil organic carbon contents were found under irrigation and reduced tillage compared with plots under irrigation and conventional tillage. In contrast, De Bona et al. (2008) did not observe significant differences between plots under conventional and no-tillage with or without irrigation.

3.4 Effects of irrigation on soil aggregate stability and soil biota

The integration of soil organic matter into microaggregates (50 to $250 \mu \mathrm{m}$ diameter) and macroaggregates $(>250 \mu \mathrm{m}$ diameter) protect it against decomposition. Carbon compounds are difficult to disrupt when bound in the matrix of silt and clay particles in connection with solid chemical exudates (Blanco-Canqiu and Lal 2004; Gillabel et al. 2007). Kong et al. (2005) consider the content of microaggregates an ideal indicator for the carbon sequestration potential of agricultural soils since additional carbon inputs are mainly fixed in these microaggregates. Other results accentuate the importance of macroaggregates for carbon sequestration. Investigations of Degens and Sparling (1995) have shown that organic carbon bound in macroaggregates was not increasingly decomposed after repeated wetting and consequently intensified microbial activity.

Soil moisture variation and hence irrigation has an important influence on soil aggregate building (Amézketa 1999). On the one hand, it is assumed that the alternation between drying and wetting has a negative impact on the stability of macroaggregates (Lehrsch et al. 1991; Mulla et al. 1992). On the other hand, investigations have shown that a continued change between wetting and drying has led to an increase in water-stable aggregates (Utomo and Dexter 1982; Dexter 1988; Barzegar et al. 1995). The effect seems to depend on soil type and soil composition. Pore volume, pore diameter, contents of clay and organic matter are important factors (Amézketa 1999; Six et al. 2004). The velocity of moisture infiltration in soil aggregates may be relevant as well (Barzegar et al. 1995). If moisture infiltrates slowly, there is little effect on soil aggregate stability in most cases. In contrast, a rapid moisture infiltration may lead to disaggregation. This depends on the water saturation of the soil in particular (Amézketa 1999).

Likewise, the intensity of irrigation may affect aggregate building and therefore the soil organic carbon content. In their investigations on deficit irrigation, Blanco-Canqui et al. (2010) found that an increase in the amount of applied irrigation water led to more soil aggregates with a diameter over $0.5 \mathrm{~mm}$, while aggregates under $0.5 \mathrm{~mm}$ decreased. Also, the soil organic carbon content increased with higher amounts of applied water. Besides the rate and duration, the system of irrigation may also influence structural stability. Furrow and flood irrigation led to disaggregation by compression of entrapped air due to rapid soil wetting (Amézketa 1999). In addition, sprinkler irrigation may influence aggregate forming at the soil surface. Water drops may increase the aggregate breakdown on the soil surface by their impact forces. This depends on drop size and fall height (Shainberg et al. 1992).

The effects of irrigation on mesofauna are relevant as well with respect to aggregate building.

The important role of soil organisms like earth worms for building clay-humus complexes makes them essential for long-term carbon storage in soils (Pulleman et al. 2005). Amador et al. (2005) registered that earth worms (Lumbricus terrestris L.) decompose more organic matter 
in a wet soil than under dry conditions. Also, the amounts of springtails (Collembola), mites (Acari) and nematodes (Nematoda) are higher under irrigation (Lindberg et al. 2002).

Soil-borne fungi are essential for aggregate building. Mycorrhiza fungi, particularly, act in multifaceted ways on the formation of soil aggregates. This occurs primarily by the growth of hyphae, which supports the complex building of microaggregates and by the excretion of secondary synthesis products. The secondary synthesis products could act directly on soil particles or influence other soil living organisms (Rilling and Mummy 2006). The effect of irrigation on mycorrhiza fungi has not been definitely ascertained. Mitra et al. (2006) did not find a significant increase of mycorrhiza infections on wheat roots under irrigation. Rillig et al. (2001) found that increased soil moisture affected hyphae length negatively.

Another mechanism to affect soil biota via irrigation might be the cooling of the soil surface. Investigations in Mongolia conducted by Mariko et al. (2007) showed that irrigation led to a fast decease in soil surface temperature from $30{ }^{\circ} \mathrm{C}$ to $20{ }^{\circ} \mathrm{C}$ and a short-term increase in $\mathrm{CO}_{2}$ generation, which indicates higher microbial activity. Optimal soil temperature for microorganisms depends on the specific soil microbial communities. O'Connel (1990) sees the optimum at $30{ }^{\circ} \mathrm{C}$, while Thierron and Laudelout (1996) found the highest microbial activity between $20^{\circ} \mathrm{C}$ and $25{ }^{\circ} \mathrm{C}$. In hot climates, where the temperatures of soil surface are often high, irrigation may support microbial activity not only by providing moisture but also by cooling the soil. This may lead to an increased decomposition of soil organic matter.

\subsection{Summary on irrigation and soil organic carbon}

The results of long term-investigations show that the effect of irrigation strongly depends on climate and initial soil organic carbon content. Positive effects of irrigation on soil organic carbon become less pronounced at higher initial soil organic carbon contents and higher precipitation. Desert soils with very low soil moisture contents and minimal carbon contents have a lower natural activity of soil biota. Inputs of carbon by the cultivation of crops exceed the microbial decomposition. Soils with higher initial carbon contents and higher soil moisture offer better living conditions for microorganisms and usually have a higher natural activity of soil biota. In these soils, there is often a balance between carbon input and carbon decomposition. Therefore, the effect of irrigation may be twofold. Irrigation, while enhancing the carbon input through larger amounts of plant residues, could additionally improve the living conditions for microorganisms, causing higher decomposition rates. Thus, the increased input of carbon could be decomposed completely. A further reduction in soil organic carbon content is even possible. The combination of irrigation with other agronomic management factors also influences the development of soil organic carbon content. Nitrogen fertilisation promotes plant growth but may lead to a change in the carbon/nitrogen ratio and hence to a higher decomposability of soil organic carbon. Tillage influences soil aeration and soil structure and hence the decomposability of soil organic carbon and the activity of soil living microorganisms. In addition to increased input of carbon by improved plant growth, irrigation shows direct effects on soil aggregate building and thus on the ability of soil to fix organic carbon long-term.

\section{Irrigation and nitrous oxide emissions}

\subsection{Overview of experiments}

There are few investigations directly comparing $\mathrm{N}_{2} \mathrm{O}$ emissions from irrigated and non-irrigated land. An overview of eight field experiments carried out in different regions of the world is given in Table 3. In most cases, $\mathrm{N}_{2} \mathrm{O}$ emissions increased under irrigation. Investigations carried out in Finland by Simojoki and Jaakkola (2000) show that $\mathrm{N}_{2} \mathrm{O}$ emissions were significantly higher under irrigation, both with and without $\mathrm{N}$ fertilisation. These investigations demonstrate that the availability of reactive nitrogen compounds has an essential influence on the amount of $\mathrm{N}_{2} \mathrm{O}$ emissions. The $\mathrm{N}_{2} \mathrm{O}$ emissions from a soil under vegetation were clearly lower than from a fallow soil without vegetation. Plants take up nitrogen from soil and, thus, reduce the nitrification and denitrification potential. Liu et al. (2011), who carried out investigations in China, likewise observed that irrigation events led to higher $\mathrm{N}_{2} \mathrm{O}$ emissions only in combination with adequate nitrogen availability. Comparing irrigated wheat and maize fields with and without $\mathrm{N}$ fertilisation, higher $\mathrm{N}_{2} \mathrm{O}$ emissions were obtained from the fertilised fields.

Livesly et al. (2010), who investigated the effects of fertilisation, irrigation and mulching on $\mathrm{N}_{2} \mathrm{O}$ emissions from urban lawns in Australia, report a continuous increase in $\mathrm{N}_{2} \mathrm{O}$ emissions under weekly irrigation, whereas the increase after fertilising was short-term. They conclude that the effect of regular irrigation is higher than that of $\mathrm{N}$ fertilisation.

Horváth et al. (2010) report an increase in $\mathrm{N}_{2} \mathrm{O}$ emissions from irrigated pastures in Hungary. This effect was observed in 2 of 3 years, in particular, when precipitation was low and the differences in water-filled pore volume between the irrigated and non-irrigated plots were large.

Scheer et al. (2008) investigated cotton fields in Uzbekistan. They found that a reduced application of water 


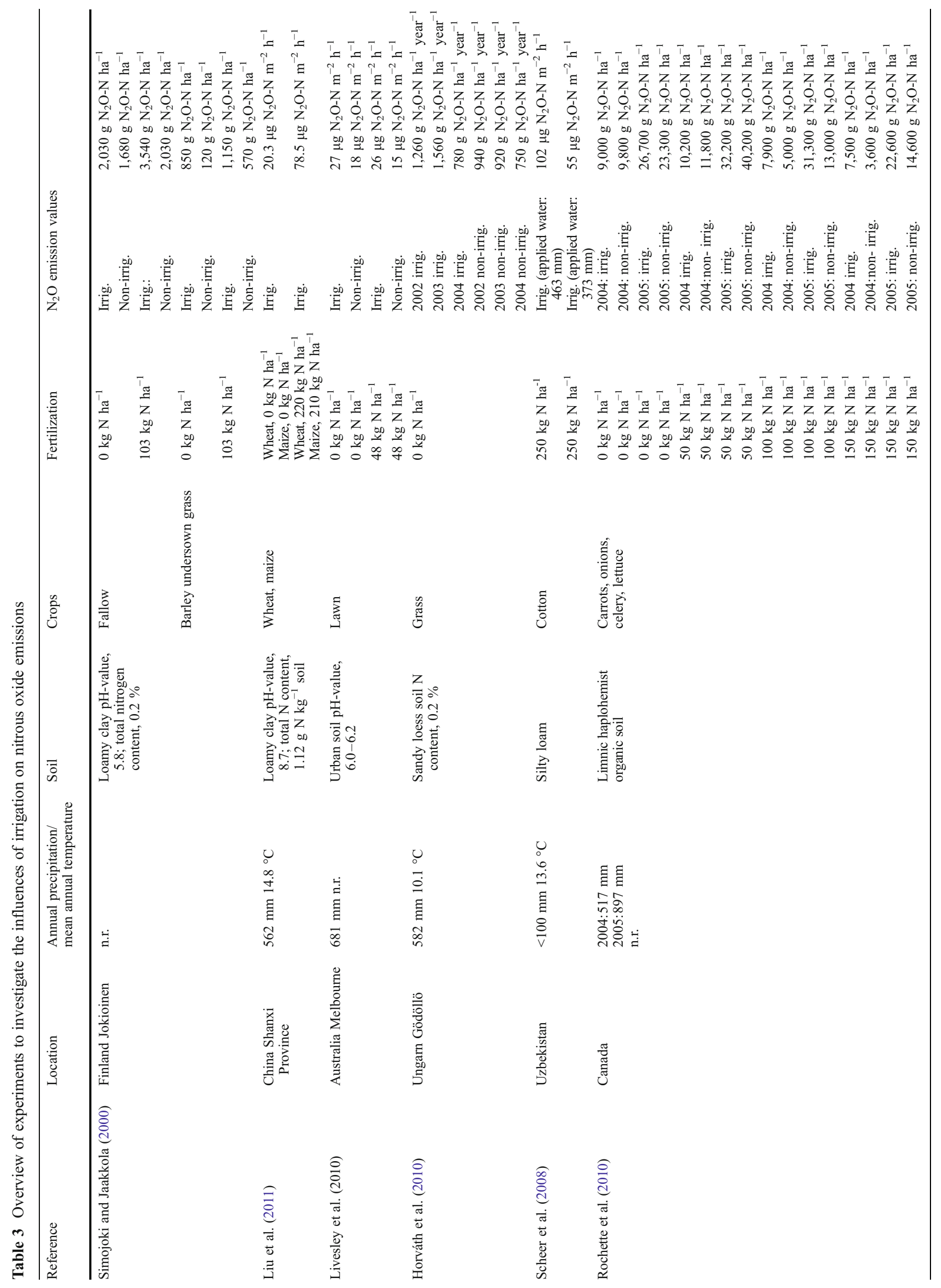


by less frequent irrigation events could lead to lower $\mathrm{N}_{2} \mathrm{O}$ emissions as a result of lower soil moisture.

Rochette et al. 2010, who investigated the effects of irrigation and $\mathrm{N}$ fertilisation on a drained organic soil in a 2-year study in Canada, obtained higher $\mathrm{N}_{2} \mathrm{O}$ emissions on irrigated plots where nitrogen fertiliser was applied. Moreover, higher amounts of precipitation and irrigation water in the second year led to increased $\mathrm{N}_{2} \mathrm{O}$ emissions.

In contrast, no significant differences between $\mathrm{N}_{2} \mathrm{O}$ emissions from irrigated and non-irrigated land are reported from two further field experiments. Liu et al. (2008) did not observe significant increases in $\mathrm{N}_{2} \mathrm{O}$ emissions from irrigated pastures in the Mongolian steppe. They consider the reason to be the low content of reactive nitrogen compounds in the soil. Also, Wulf et al. (1999), who conducted their investigations in Kenya, found that the amount of $\mathrm{N}_{2} \mathrm{O}$ emissions did not differ significantly from irrigated and non-irrigated plots. After irrigation or precipitation events, increases of $\mathrm{N}_{2} \mathrm{O}$ emissions were observed in both variants. Under irrigation, the increase was slightly smaller. This is explained by the availability of reactive nitrogen compounds, since the nitrate contents in the irrigated plots were lower. Without irrigation, the microbial activity and, hence, mineralisation, nitrification and denitrification processes were reduced in the dry period. These processes were enhanced rapidly with an increase in soil moisture after precipitation and caused a strong release and conversion of reactive nitrogen compounds. Living conditions for microorganisms are more favourable and constant under irrigation so that mineralisation and conversion proceed more steadily (Wulf et al. 1999).

\subsection{Influence of soil water content and soil aeration} on nitrous oxide emissions

$\mathrm{N}_{2} \mathrm{O}$ arises as an intermediate in denitrification and nitrification. Both processes are strongly influenced by soil water content and soil aeration. Low oxygen contents and anaerobic conditions caused by high soil water content can lead to intensification of denitrification processes (Beare et al. 2009). $\mathrm{N}_{2} \mathrm{O}$ emissions arising from denitrification processes increase strongly at a water filled pore volume over $70 \%$ (Amha and Bohne 2011; Ruser et al. 2006). However, a nearly complete filling of the pore volume over a long time may lead to a decrease of $\mathrm{N}_{2} \mathrm{O}$ emissions since, under strict anaerobic conditions, the intermediate in denitrification $\mathrm{N}_{2} \mathrm{O}$ is completely deoxidised to $\mathrm{N}_{2}$ (Huang et al. 2007).

Nitrification is the primary reason for $\mathrm{N}_{2} \mathrm{O}$ formation under oxygen availability. A water-filled pore volume of $30 \%$ to $60 \%$ supports $\mathrm{N}_{2} \mathrm{O}$ release via nitrification (Kavdir et al. 2008; Horváth et al. 2010). Also, the kind of tillage may affect soil aeration and, thus, the processes generating $\mathrm{N}_{2} \mathrm{O}$. There are many investigations regarding 
the impact of reduced or minimum tillage on $\mathrm{N}_{2} \mathrm{O}$ release, reporting that reduced tillage leads to higher $\mathrm{N}_{2} \mathrm{O}$ emissions in comparison to conventional tillage (Abdalla et al. 2010; Ball et al. 2008; Rochette 2008; Smith et al. 2000). In contrast, some results have shown higher $\mathrm{N}_{2} \mathrm{O}$ emissions from soils under conventional tillage (Chatskikh and Olesen 2007; Gregorich et al. 2007; Mutegi et al. 2010). The increased $\mathrm{N}_{2} \mathrm{O}$ emissions under reduced or minimum tillage can be explained by a reduced gas exchange and resultant intensified denitrification processes (Abdalla et al. 2010; Ball et al. 2008; Rochette 2008). Also, increased $\mathrm{CO}_{2}$ production from microbial respiration caused by the accumulation of organic matter in the top soil under no-till leads to a decrease in oxygen concentration (Abdalla et al. 2010). The reason for higher $\mathrm{N}_{2} \mathrm{O}$ emissions under conventional tillage could be a strong disaggregation and enhanced soil aeration. Hence, the living conditions of aerobic nitrifying bacteria may be improved (Elmi et al. 2003; Gregorich et al. 2007).

4.3 Nitrous oxide emissions under irrigation in combination with nitrogen fertilising

In those investigations where higher $\mathrm{N}_{2} \mathrm{O}$ emissions were observed under irrigation, the availability of nitrogen was

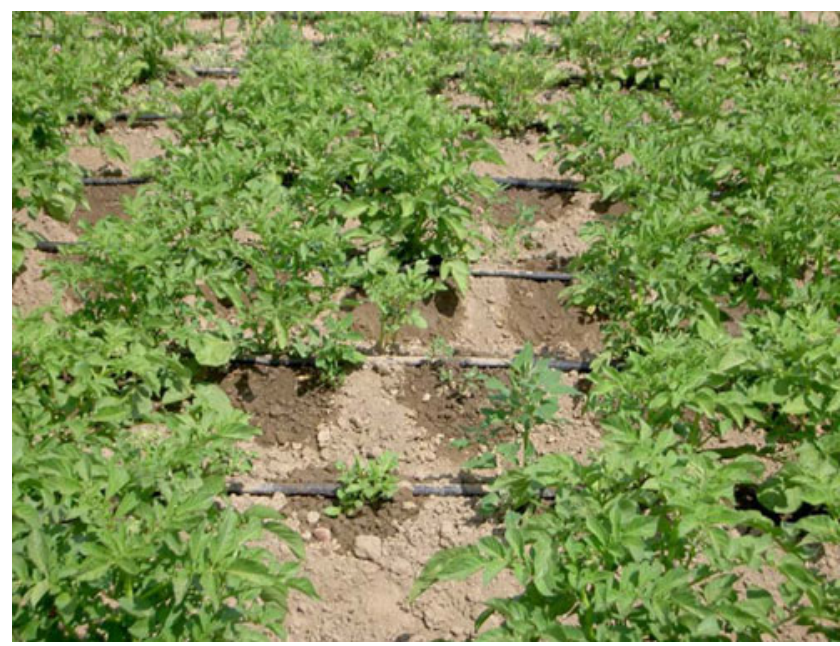

Fig. 6 Drip irrigation, partial wetting of soil

most often the more relevant factor (Fig. 5). An average increase of about $87 \%$ was estimated under irrigation in combination with nitrogen fertilising. Without nitrogen, fertilising the estimated average increase was about $7 \%$. But exceptions with high increases in $\mathrm{N}_{2} \mathrm{O}$ emissions under irrigation without nitrogen fertilisation are possible. According to Robertson et al. (2000), the primary reason change in amount of $\mathrm{N}_{2} \mathrm{O}$ emissions (\%)

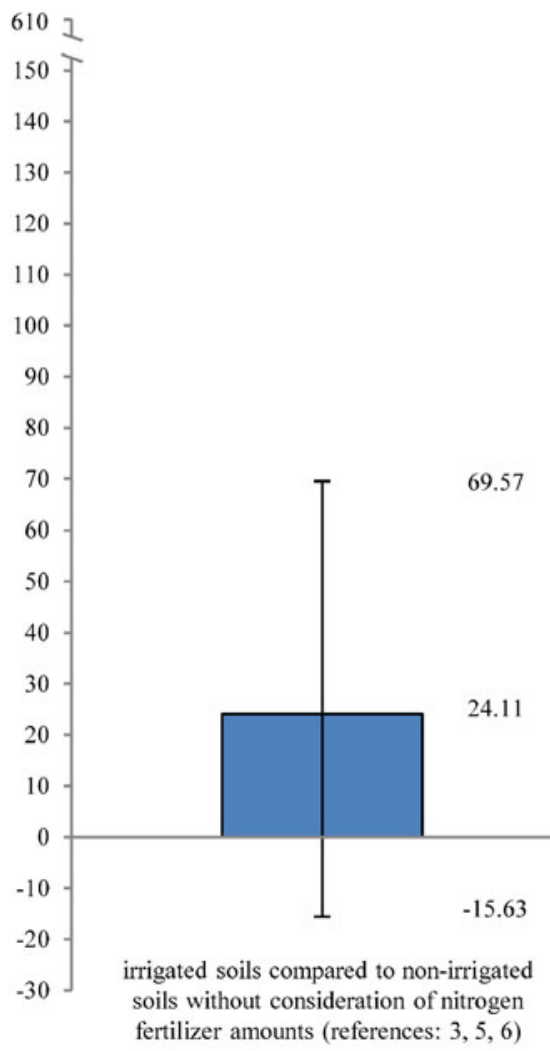

$$
608.38 *
$$

one result

with a strong

increase of

$\mathrm{N}_{2} \mathrm{O}$ emissions

under

irrigation in

connection with a

low $\mathrm{N}$-fertilization

(reference: 1)

a

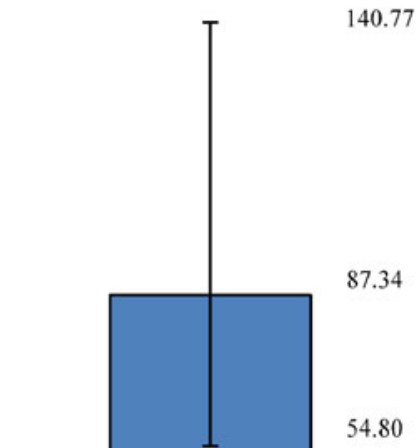

20.83

7.30

$-19.90$

irrigated soils compared to non-irrigated soils in connection with low $\mathrm{N}$-fertilizer amounts (references: 1, 2, 4)

irrigated soils compared to non-irrigated soils in connection with high $\mathrm{N}$-fertilizer amounts (references $(1,2,4)$
Fig. 5 Changes (mean, minimum maximum) in $\mathrm{N}_{2} \mathrm{O}$ emissions under irrigation compared with non-irrigated conditions, based on six investigations (references: $1=$ Simojoki and Jaakkola (2000); $2=$ Livesley et al. (2010); 3=Horváth et al. (2010); 4=Rochette et al. (2010); 5=Liu et al. (2008); $6=$ Wulf et al. (1999)) 
for high $\mathrm{N}_{2} \mathrm{O}$ emissions is the existence of a high concentration of reactive nitrogen compounds in the soil. Irrigated arable land as a rule is intensively farmed and, therefore, has a high fertiliser input. Consequently, it offers a high potential for $\mathrm{N}_{2} \mathrm{O}$ formation (Ellert and Janzen 2008). It has been affirmed in numerous investigations that an increase in nitrogen fertilising leads to higher $\mathrm{N}_{2} \mathrm{O}$ emissions (Clayton et al. 1997; Hao et al. 2001; Lin et al. 2011; Liu and Greaver 2009; Yao et al. 2010). An increase in the water-filled pore volume can intensify this effect additionally (Abbasi and Adams 2000). Significantly higher emissions were observed in several investigations if precipitation and irrigation events proceeded after the application of nitrogen fertiliser (Dobbie and Smith 2003; Liu et al. 2010; Hutchinson and Mosier 1979; Scheer et al. 2008).

\subsection{Effects of irrigation systems on nitrous oxide emissions}

The irrigation technology and hence the distribution of water in the soil may affect the amount of $\mathrm{N}_{2} \mathrm{O}$ emissions. Sanchez-Martin et al. (2010) and Kallenbach et al. (2010) found that $\mathrm{N}_{2} \mathrm{O}$ emissions were lower under drip irrigation than under furrow irrigation. According to Kallenbach et al. (2010), the reason is the partial wetting of soil under drip irrigation (Fig. 6). The soil pore volume is filled with water only at the spots where the drippers are located. Thus, denitrification proceeds on a considerably smaller area in comparison to furrow irrigation. Nelson and Terry (1996) compared $\mathrm{N}_{2} \mathrm{O}$ emissions under sprinkler irrigation and furrow irrigation. They observed strong changes in soil physical parameters under furrow irrigation. Increases in bulk density and crusting led to a decrease in aeration and, therefore, to an intensification of denitrification processes. At the same time, crusting may prevent $\mathrm{N}_{2} \mathrm{O}$ from directly escaping from the soil to the atmosphere, so that $\mathrm{N}_{2} \mathrm{O}$ may possibly deoxidise to $\mathrm{N}_{2}$ (Mahmood et al. 2008).

\subsection{Summary on irrigation and $\mathrm{N}_{2} \mathrm{O}$ emissions}

In summary, general statements on the effect of irrigation on the amount of $\mathrm{N}_{2} \mathrm{O}$ emissions cannot yet be derived. In various cases, an increase in soil moisture intensified nitrification and denitrification processes and, thus, enhanced $\mathrm{N}_{2} \mathrm{O}$ emissions. Direct comparisons between the amount of $\mathrm{N}_{2} \mathrm{O}$ emissions from irrigated and nonirrigated land are rare. Those available did not always find higher $\mathrm{N}_{2} \mathrm{O}$ emissions from the irrigated plots. In most cases, the availability of reactive nitrogen compounds seems to be more important for the release of $\mathrm{N}_{2} \mathrm{O}$. Different technologies and intensities of irrigation may also influence $\mathrm{N}_{2} \mathrm{O}$ emissions.

\section{Conclusions}

In most cases, irrigation leads to significantly higher soil organic carbon contents in arid soils and deserts than nonirrigated conditions. For humid climates and on soils with higher initial soil organic carbon content, irrigation has no significant effects on soil organic carbon contents. $\mathrm{N}_{2} \mathrm{O}$ emissions as a rule increase under irrigation when reactive nitrogen compounds are adequately available. Soil carbon sequestration and $\mathrm{N}_{2} \mathrm{O}$ release are affected by environmental factors and management measures interacting with irrigation. It is difficult to estimate the effects of some of these factor combinations. The net effects of irrigation on greenhouse gas emissions have not been estimated yet. A full balance is necessary to assess the impact of irrigation on net greenhouse gas emissions.

\section{References}

Abbasi MK, Adams WA (2000) Gaseous N emission during simultaneous nitrification-denitrification associated with mineral $\mathrm{N}$ fertilization to a grassland soil under field conditions. Soil Biol Biochem 32:1251-1259. doi:10.1016/S0038-0717(00)00042-0

Abdalla M, Jones M, Williams M (2010) Simulation of $\mathrm{N}_{2} \mathrm{O}$ fluxes from Irish arable soils: effect of climate change and management. Biol Fert Soils 46:247-260. doi:10.1007/s00374-009-0424-5

Alexandratos N, Bruinsma J (2012) World agriculture towards 2030/ 2050: the 2012 revision. ESA Working paper, Rome, FAO, No. $12-03$

Amador JA, Görres JH, Savin MC (2005) Role of soil water content in carbon and nitrogen dynamics of Lumbricus terrestris L. burrow soil. Appl Soil Ecol 28:15-22. doi:10.1016/j.apsoil.2004.06.009

Amézketa E (1999) Soil aggregate stability: a review. J Sustain Agric 14:83-151

Amha Y, Bohne H (2011) Denitrification from the horticultural peats: effects of $\mathrm{pH}$, nitrogen, carbon and moisture contents. Biol Fert Soils 47:293-302. doi:10.1007/s00374-010-0536-y

Ball BC, Crichton I, Horgan GW (2008) Dynamics of upward and downward $\mathrm{N}_{2} \mathrm{O}$ and $\mathrm{CO}_{2}$ fluxes in ploughed or no-tilled soils in relation to water-filled pore space, compaction and crop presence. Soil Till Res 101:20-30. doi:10.1016/j.still.2008.05.012

Barzegar AR, Rengasamy P, Oades JN (1995) Effects of clay type and rate of wetting on the mellowing of compacted soils. Geoderma 68:39-40. doi:10.1016/0016-7061(95)00022-g

Beare MH, Gregorich EG, St-Georges P (2009) Compaction effects on $\mathrm{CO}_{2}$ and $\mathrm{N}_{2} \mathrm{O}$ production during drying and rewetting of soil. Soil Biol Biochem 41:611-621. doi:10.1016/j.soilbio.2008.12.024

Blanco-Canqiu H, Lal R (2004) Mechanisms of carbon sequestration in soil aggregates. Crit Rev Plant Sci 23:481-504. doi:10.1080/ 07352680490886842

Blanco-Canqui H, Klocke NL, Schlegel AJ, Stone LR, Rice CW (2010) Impacts of deficit irrigation on carbon sequestration and soil physical properties under no-till. Soil Sci Soc Am J 74:13011309. doi:10.2136/sssaj2009.0364

Bordovsky DG, Choudhary M, Gerard CJ (1999) Effect of tillage, cropping, and residue management on soil properties in the Texas Rolling Plains. Soil Sci 164:331-340. doi:10.1097/ 00010694-199905000-00005

Bremner JM (1997) Sources of nitrous oxide in soils. Nutr Cycl Agroecosyst 49:7-16. doi:10.1023/a:1009798022569 
Bruinsma J (2009) The resource outlook to 2050: by how much do land, water and crop yields need to increase by 2050 ? How to feed the world in 2050. Proceedings of a technical meeting of experts. FAO (Food and Agriculture Organization of the United Nations), Rome, Italy, http://www.fao.org/wsfs/forum2050/wsfs-backgrounddocuments/wsfs-expert-papers/en/ Accessed 10 December 2012

Chatskikh D, Olesen JE (2007) Soil tillage enhanced $\mathrm{CO}_{2}$ and $\mathrm{N}_{2} \mathrm{O}$ emissions from loamy sand soil under spring barley. Soil Till Res 97:5-18. doi:10.1016/j.still.2007.08.004

Clayton H, McTaggart IP, Parker J, Swan L (1997) Nitrous oxide emissions from fertilised grassland: a 2-year study of the effects of $\mathrm{N}$ fertiliser from environmental conditions. Biol Fertil Soils 25:252-260. doi:10.1007/s003740050311

De Bona FD, Bayer C, Dieckow J, Bergamaschi H (2008) Soil quality assessed by carbon management index in a subtropical Acrisol subjected to tillage systems and irrigation. Aust J Soil Res 46:469-475. doi:10.1071/sr08018

Degens BP, Sparling GP (1995) Repeated wet-dry cycles do not accelerate the mineralization of organic $\mathrm{C}$ involved in the macro-aggregation of a sandy loam soil. Plant Soil 175:197203. doi:10.1007/BF00011355

Denef K, Stewart CE, Brenner J, Paustian K (2008) Does long-term center-pivot irrigation increase soil carbon stocks in semi-arid agro-ecosystems? Geoderma 145:121-129. doi:10.1016/ j.geoderma.2008.03.002

Deng X-P, Shan L, Inanaga S, Inoue M (2005) Water-saving approaches for improving wheat production. J Sci Food Agric 85:1379-1388. doi:10.1002/jsfa.2101

Dersch G, Bohm K (2001) Effects of agronomic practices on the soil carbon storage potential in arable farming in Austria. Nutr Cycl Agroecosyst 60:49-55. doi:10.1023/a:1012607112247

Dexter AR (1988) Advances in characterization of soil structure. Soil Till Res 11:199-238. doi:10.1016/0167-1987(88)90002-5

Dobbie KE, Smith A (2003) Nitrous oxide emissions factors for agricultural soils in Great Britain: the impact of soil water-filled pore space and other controlling variables. Glob Change Biol 9:204-218. doi:10.1046/j.1365-2486.2003.00563.x

Drastig K, Prochnow A, Baumecker M, Berg W, Brunsch R (2011) Agricultural water management in Brandenburg. Erde 142:119-140

Elmi AA, Madramootoo C, Hamel C, Liu A (2003) Denitrification and nitrous oxide to nitrous oxide plus dinitrogen ratios in the soil profile under three tillage systems. Biol Fert Soils 38:340-348. doi:10.1007/s00374-003-0663-9

Ellert BH, Janzen HH (2008) Nitrous oxide, carbon dioxide and methane emissions from irrigated cropping systems as influenced by legumes, manure and fertilizer. Can J Soil Sci 88:207-217. doi: $10.4141 /$ CJSS06036

Ellmer F, Baumecker M (2002) 65 years long-term experiments at Thyrow. Results for sustainable crop production at Sandy Soils. Arch Acker Pfl Boden 48:521-531. doi:10.1080/03650340215639

Entry JA, Sojka RE, Shewmaker GE (2004) Irrigation increases inorganic carbon in agricultural soils. Environ Manage 33:309-317. doi:10.1007/s00267-003-9140-3

Entry JA, Mills D, Mathee K, Jayachandran K, Sojka RE, Narasimhan G (2008) Influence of irrigated agriculture on soil microbial diversity. Appl Soil Ecol 40:146-154. doi:10.1016/j.apsoil.2008.03.012

Fallahzade J, Hajabbasi MA (2012) The effects of irrigation and cultivation on the quality of desert soil in central Iran. Land Degrad Dev 23:53-61. doi:10.1002/ldr.1049

FAO (Food and Agriculture Organization of the United Nations) Statistical yearbook (2010) http://www.fao.org/economic/ess/esspublications/ess-yearbook/ess-yearbook2010/yearbook2010reources/en/ Accessed 22 August 2011

Getaneh F, Deressa A, Negassa W (2007) Influence of small scale irrigation on selected soil chemical properties. Tropentag, Witzenhausen, Germany, 2007 October 9-11
Gillabel J, Denef K, Brenner J, Merckx R, Paustian K (2007) Carbon sequestration and soil aggregation in center-privot irrigated and dryland cultivated farming systems. Soil Sci Soc Am J 71:1020 1028. doi: $10.2136 /$ sssaj2006.0215

Gregorich EG, Rochette P, St-Georges P, Mckim UF, Chan C (2007) Tillage effects on $\mathrm{N}_{2} \mathrm{O}$ emissions from soils under corn and soybeans in Eastern Canada. Can J Soil Sci 88:153-161. doi:10.4141/CJSS06041

Hao X, Chang C, Carefoot JM, Janzen HH, Ellert BH (2001) Nitrous oxide emissions from an irrigated soil as affected by fertilizer and straw management. Nutr Cycl Agroecosys 60:1-8. doi:10.1023/ A:1012603732435

Horváth L, Grosz B, Machon A, Tuba Z, Nagy Z, Czóbel SZ, Balogh J, Péli E, Fòti SZ, Weidinger T, Pintér K, Führer E (2010) Estimation of nitrous oxide emissions from Hungarian semi-arid sandy and loess grasslands; effect of soil parameters, grazing, irrigation and use of fertilizer. Agr Ecosyst Environ 139:255263. doi:10.1016/j.agee.2010.08.011

Huang S, Pant HK, Lu J (2007) Effects of water regimes on nitrous oxide emission from soils. Ecol Eng 31:9-15. doi:10.1016/ j.ecoleng.2007.04.001

Hutchinson GL, Mosier AR (1979) Nitrous oxide emissions from an irrigated cornfield. Science 205:1125-1127. doi:10.1126/ science.205.4411.1125

Jabro JD, Sainju U, Stevens WB, Evans RG (2008) Carbon dioxide flux as affected by tillage and irrigation in soil converted from perennial forages to annual crops. J Environ Manage 88:14781484. doi:10.1016/j.jenvman.2007.07.012

Jha PB, Singh JS, Kashyap AK (1996) Dynamics of viable nitrifier community and nutrient availability in dry tropical forest habitat as affected by cultivation and soil texture. Plant Soil 180:277285. doi:10.1007/bf00015311

Kallenbach CM, Rolston DE, Horwath WR (2010) Cover cropping affects soil $\mathrm{N}_{2} \mathrm{O}$ and $\mathrm{CO}_{2}$ emissions differently depending on type of irrigation. Agr Ecosyst Environ 137:251-260. doi:10.1016/ j.agee.2010.02.010

Kavdir Y, Hellebrand HJ, Kern J (2008) Seasonal variations of nitrous oxide emissions in relation to nitrogen fertilization and energy crop types in sandy soil. Soil Till Res 98:175-186. doi:10.1016/ j.still.2007.11.002

King AP, Evatt KJ, Six J, Poch RM, Rolston DE, Hopmans JW (2009) Annual carbon and nitrogen loadings for a furrowirrigated field. Agr Water Manage 96:925-930. doi:10.1016/ j.agwat.2009.01.001

Kochsiek AE, Knops JMH, Walters DT, Arkebauer TJ (2009) Impacts of management on decomposition balance in irrigated and rainfed no till agricultural systems. Agr Forest Meteorol 149:1983-1993. doi:10.1016/j.agrformet.2009.07.004

Kong AYY, Six J, Bryant DC, Denison RF, van Kessel C (2005) The relationship between carbon input, aggregation, and soil organic carbon stabilization in sustainable cropping systems. Soil Sci Soc Am J 69:1078-1085. doi:10.2136/sssaj2004.0215

Lal R (2004) Soil carbon sequestration impacts on global climate change and food security. Science 304:1623-1627. doi:10.1126/ science. 1097396

Lehrsch GA, Sojka RE, Carter DL, Jolley PM (1991) Freezing effects on aggregate stability affected by texture, mineralogy, and organic matter. Soil Sci Soc Am J 55:1401-1406

Li C, Frolking S, Butterbach-Bahl K (2005) Carbon sequestration in arable soils is likely to increase nitrous oxide emissions, offsetting reductions in climate radiative forcing. Clim Chang 72:321-338. doi:10.1007/s10584-005-6791-5

Li C, Frolking S, Crocker GJ, Grace PR, Klír J, Körchens M, Poulton PR (1997) Simulating trends in soil organic carbon in long-term experiments using the DNDC model. Geoderma 81:45-60. doi:10.1016/S0016-7061(97)00080-3 
Li XG, Li YK, Li FM, Ma Q, Zhang PL, Yin P (2009) Changes in soil organic carbon, nutrients and aggregation after conversion of native desert soil into irrigated arable land. Soil Till Res 104:263-269. doi:10.1016/j.still.2009.03.002

Li XH, Li FM, Rengel Z, Bhupinderpal S, Wang ZF (2006) Cultivation effects on temporal changes of organic carbon and aggregate stability in desert soil of Hexi Corridor in China. Soil Till Res 91:22-29. doi:10.1016/j.still.2005.10.004

Lin S, Iqbal J, Hu R, Wu J, Zhao J, Ruan L, Malghani S (2011) Nitrous oxide emissions from rape field as affected by nitrogen fertilizer management: a case study in Central China. Atmos Environ 45:1775-1779. doi:10.1016/j.atmosenv.2011.01.003

Lindberg N, Engtsson JB, Persson T (2002) Effect of experimental irrigation and drought on the composition and diversity of soil fauna in a coniferous stand. J Appl Ecol 39:924-936. doi:10.1046/j.1365-2664.2002.00769.x

Liu L, Greaver TL (2009) A review of nitrogen enrichment effects on three biogenic GHGs: the $\mathrm{CO}_{2}$ sink may be largely offset by stimulated $\mathrm{N}_{2} \mathrm{O}$ and $\mathrm{CH}_{4}$ emission. Ecol Lett 12:1103-1117. doi:10.1111/j.1461-0248.2009.01351.x

Liu CY, Holst J, Brüggemann N, Butterbach-Bahl K, Yao ZS, Han SH, Han XG, Zheng XH (2008) Effects of irrigation on nitrous oxide, methane and carbon dioxide fluxes in an inner Mongolian steppe. Adv Atmos Sci 25:748-756. doi:10.1007/ s00376-008-0748-3

Liu CY, Wang K, Meng S, Zheng XH, Zhou ZX, Han SH, Chen D, Yang ZP (2011) Effects of irrigation, fertilization and crop straw management on nitrous oxide and nitric oxide emissions from a wheat-maize rotation field in northern China. Agr Ecosyst Environ 140:226-233. doi:10.1016/j.agee.2010.12.009

Liu CY, Zheng XH, Zhou ZX, Han SH, Wang YH, Wang K, Liang WG, Li M, Chen DL, Yang ZP (2010) Nitrous oxide and nitric oxide emissions from an irrigated cotton field in Northern China. Plant Soil 332:123-134. doi:10.1007/s11104-009-0278-5

Livesly SJ, Dougherty BJ, Smith AJ, Navaud D, Wylie LJ, Arndt SK (2010) Soil-atmosphere exchange of carbon dioxide, methane and nitrous oxide in urban garden systems: impact of irrigation, fertilizer and mulch. Urban Ecosyst 13:273-293. doi:10.1007/ s11252-009-0119-6

Loecke TD, Robertson GP (2009) Soil resource heterogeneity in terms of litter aggregation promotes nitrous oxide fluxes and slows decomposition. Soil Biol Biochem 41:228-235. doi:10.1016/ j.soilbio.2008.10.017

Mahmood T, Ali R, Iqbal J, Robab U (2008) Nitrous oxide emissions from an irrigated cotton field under semiarid subtropical conditions. Biol Fertil Soils 44:773-781. doi:10.1007/s00374-008-0276-4

Mariko S, Urano T, Asanuma J (2007) Effects of irrigation on $\mathrm{CO}_{2}$ and $\mathrm{CH}_{4}$ fluxes from Mongolian steppe soil. J Hydrol 333:118-123. doi:10.1016/j.jhydrol.2006.07.027

Martens DA, Emmerich W, Mclain JET, Johnsen TN (2005) Atmospheric carbon mitigation potential of agricultural management in southwestern USA. Soil Till Res 83:95-119. doi:10.1016/ j.still.2005.02.011

Mitra S, Singh S, Bandyopahyay SK, Singh CS (2006) Effect of irrigation, $\mathrm{N}$, and bio-fertilizers on yield and nutrient uptake by wheat. Trop Agr 83:87-94

Mulla DJ, Huyck LM, Reganold JP (1992) Temporal variation in soil aggregate stability on conventional and alternative farms. Soil Sci Soc Am J 56:1620-1624

Mutegi JK, Munkholm LJ, Petersen BM, Hansen EM, Petersen SO (2010) Nitrous oxide emissions and controls as influenced by tillage and crop residue management strategy. Soil Biol Biochem 42:1701-1711. doi:10.1016/j.soilbio.2010.06.004

Nelson SD, Terry RE (1996) The effects of soil physical properties and irrigation method on denitrification. Soil Sci 161:242-249. doi:10.1097/00010694-199604000-00005
O'Connel AM (1990) Microbial decomposition (respiration) of litter in eucalypt forests of south-western Australia: an empirical model based on laboratory incubations. Soil Biol Biochem 22:153-160. doi:10.1016/0038-0717(90)90080-J

Ogle SM, Breidt FJ, Paustian K (2005) Agricultural management impacts on soil organic carbon storage under moist and dry climatic conditions of temperate and tropical regions. Biogeochemistry 72:87-121. doi:10.1007/s10533-004-0360-2

Phillips RL (2008) Denitrification in cropping systems at sub-zero soil temperatures. A review. Agron Sustain Dev 28:87-93. doi:10.1051/agro:2007045

Potthoff M, Dyckmans J, Flessa H, Muhs A, Beese F, Joergensen RG (2005) Dynamics of maize (Zea mays L.) leaf straw mineralization as affected by the presence of soil and the availability of nitrogen. Soil Biol Biochem 37:1259-1266. doi:10.1016/j.soilbio.2004.11.022

Presley DR, Ransom MD, Kluitenberg GJ, Finnell PR (2004) Effects of thirty years of irrigation on the genesis and morphology of two semiarid soils in Kansas. Soil Sci Soc Am J 68:1916-1926

Pulleman MM, Six J, Uyl A, Marinissen JCY, Jongmans AG (2005) Earthworms and management affect organic matter incorporation and microaggregate formation in agricultural soils. Appl Soil Ecol 29:1-15. doi:10.1016/j.apsoil.2004.10.003

Rillig MC, Wright SF, Kimball BA, Pinter PJ, Wall GW, Ottman MJ, Leavitt SW (2001) Elevated carbon dioxide and irrigation effects on water stable aggregates in a sorghum field: a possible role for arbuscular mycorrhizal fungi. Glob Change Biol 7:333-337. doi:10.1046/j.1365-2486.2001.00404.x

Rilling MC, Mummey DL (2006) Mycorrhizas and soil structure. New Phytol 171:41-53. doi:10.1111/j.1469-8137.2006.01750.x

Robertson GP, Paul EA, Harwood RR (2000) Greenhouse gases in intensive agriculture: contributions of individual gases to the radiative forcing of the atmosphere. Science 289:1922-1925. doi:10.1126/science. 289.5486 .1922

Rochette $\mathrm{P}$ (2008) No-till only increases $\mathrm{N}_{2} \mathrm{O}$ emissions in poorly-aerated soils. Soil Till Res 101:97-100. doi:10.1016/j.still.2008.07.011

Rochette P, Tremblay N, Fallon E, Angers DA, Chantign MH, MacDonald JD, Bertrand N, Parent L-É (2010) $\mathrm{N}_{2} \mathrm{O}$ emissions from an irrigated and non-irrigated organic soil in eastern Canada as influenced by $\mathrm{N}$ fertilizer addition. Eur J Soil Sci 61:186-196. doi:10.1111/j.1365-2389.2009.01222.x

Roldan A, Salinas-Garcia JR, Alguacil MM, Caravaca F (2005) Changes in soil enzyme activity, fertility, aggregation and $\mathrm{C}$ sequestration mediated by conservation tillage practices and water regime in a maize field. Appl Soil Ecol 30:11-20. doi:10.1016/j.apsoil.2005.01.004

Ruser R, Flessa H, Russow R, Schmidt G, Buegger F, Munch JC (2006) Emissions of $\mathrm{N}_{2} \mathrm{O}, \mathrm{N}_{2}$ and $\mathrm{CO}_{2}$ from soil fertilized with nitrate: effect of compaction, soil moisture and rewetting. Soil Biol Biochem 38:263-274. doi:10.1016/j.soilbio.2005.05.005

Rusu T et al (2008) The influence of minimum soil tillage systems on water and humus conservation in some soils of Romania. Agricultural and biosystems engineering for a sustainable world. International Conference on Agricultural Engineering, Hersonissos, Crete, Greece, pp 177-183, 23-25 June 2008

Sanchez-Martin L, Meijide A, Garcia-Torres L, Vallejo A (2010) Combination of drip irrigation and organic fertilizer for mitigating emissions of nitrogen oxides in semiarid climate. Agr Ecosyst Environ 137:99-107. doi:10.1016/j.agee.2010.01.006

Scheer C, Wassmann R, Kienzler K, Ibragimov N, Eschanov R (2008) Nitrous oxide emissions from fertilized cotton (Gossypium hirsutum L.) in the Aral Sea Basin, Uzbekistan: influence of nitrogen applications and irrigation practices. Soil Biol Biochem 40:290 301. doi:10.1016/j.soilbio.2007.08.007

Schlesinger WH (2000) Some cautions amidst optimism. Agr Ecosyst Environ 82:121-127

Shainberg I, Levy GJ, Rengasamy P, Frenkel H (1992) Aggregate stability and seal formation as affected by drops impact energy 
and soil amendments. Soil Sci 154:113-119. doi:10.1097/ 00010694-199208000-00004

Simojoki A, Jaakkola A (2000) Effect of nitrogen fertilization, cropping and irrigation on soil air composition and nitrous oxide emissions in a loamy clay. Eur J Soil Sci 51:413-424. doi:10.1046/j.1365-2389.2000.00308.x

Šimon T, Javůrek M, Mikanová O, Vach M (2009) The influence of tillage systems on soil organic matter and soil hydrophobicity. Soil Till Res 105:44-48

Six J, Bossuyt H, Degryze S, Denef K (2004) A history of research on the link between (micro)aggregates, soil biota, and soil organic matter dynamics. Soil Till Res 79:7-31. doi:10.1016/j.still.2004.03.008

Smith P, Goulding KWT, Smith KA, Powlson DS, Smith JU, Falloon $P$, Coleman K (2000) Including trace gas fluxes in estimates of the carbon mitigation potential of UK agricultural land. Soil Use Manage 16:251-259. doi:10.1111/j.1475-2743.2000.tb00204.x

Stubbs TL, Kennedy AC, Schillinger WF (2004) Soil ecosystem changes during the transition to no-till cropping. J Crop Imp 11:105-135. doi:10.1300/J411v11n01_06

Su YZ, Yang R, Liu WJ, Wang XF (2010) Evolution of soil structure and fertility after conversion of native sandy desert soil to irrigated cropland in arid region, China. Soil Sci 175:246-254. doi:10.1097/SS.0b013e3181e04a2d

Thierron V, Laudelout H (1996) Contribution of root respiration to total $\mathrm{CO}_{2}$ efflux from the soil of a deciduous forest. Can J Forest Res 26:1142-1148. doi:10.1139/x26-127

Utomo WH, Dexter AR (1982) Changes in soil aggregate water stability induced by wetting and drying cycles in non-saturated soil. J Soil Sci 33:623-637. doi:10.1111/j.1365-2389.1982.tb01794.x

Wu L, Wood Y, Jiang P, Li L, Pan G, Lu J, Chang AC, Enloe HA (2008) Carbon sequestration and dynamics of two irrigated agricultural soil in California. Soil Sci Soc Am J 72:808-814. doi:10.2136/sssaj2007.0074

Wulf S, Lehmann J, Zech W (1999) Emissions of nitrous oxide from runoff-irrigated and rainfed soils in semiarid north-west Kenya. Agr Ecosyst Environ 72:201-205. doi:10.1016/S01678809(98)00172-8

Yao Z, Zhou Z, Zheng Y, Xie B, Mei B, Wang R, ButterbachBahl K, Zhu J (2010) Effects of organic matter incorporation on nitrous oxide emissions from rice-wheat rotation ecosystems in China. Plant Soil 327:315-330. doi:10.1007/s11104009-0056-4 